\title{
Development and Validation of KASP Markers for the Identification of Pea seedborne mosaic virus Pathotype P1 Resistance in Pisum sativum
}

\author{
Kylie D. Swisher Grimm ${ }^{1}$ and Lyndon D. Porter ${ }^{2, \dagger}$ \\ ${ }^{1}$ Temperate Tree Fruit and Vegetable Research Unit, U.S. Department of Agriculture Agricultural Research Service, Prosser, \\ WA 99350 \\ ${ }^{2}$ Grain Legume Genetics and Physiology Research Unit, U.S. Department of Agriculture Agricultural Research Service, Prosser, \\ WA 99350
}

\begin{abstract}
As pesticides have become heavily relied on for management of insect pests vectoring economically important pathogens of vegetable crops, development of pathogen-resistant germplasm remains a promising alternative to reduce or eliminate costly and timely chemical inputs. Molecular markers can be used to rapidly identify resistant genotypes to aid breeders in advancing germplasm. This study developed two kompetitive allele-specific PCR (KASP) genotyping markers for rapid screening of Pisum sativum genotypes for resistance to Pea seedborne mosaic virus pathotype P1 (PSbMV-P1), the most economically devastating strain worldwide. The KASP markers differentiate two eIF4E

for marker design. Forty-four $P$. sativum lines previously characterized for resistance to PSbMV were inoculated with PSbMV-P1 in a greenhouse, observed for visual symptoms, assayed for virus susceptibility by enzyme-linked immunosorbent assay (ELISA), and genotyped by KASP marker analysis. The KASP markers were $100 \%$ accurate in characterizing PSbMV-P1-susceptible and PSbMV-P1-resistant genotypes when correlated with the ELISA results. The Resistant 1 marker also correlated with resistance to PSbMV pathotypes P2 and P4 completely, making this marker a new advanced tool for $P$. sativum breeding programs.
\end{abstract} PSbMV-P1-resistant allelic variants from susceptible $e I F 4 E$ variants. A single nucleotide polymorphism (Resistant 1) and a 3-basepair deletion (Resistant 2) present in either of the two resistant alleles were used
Keywords: KASP marker, Pea seedborne mosaic virus, Pisum sativum, PSbMV
The species Pea seedborne mosaic virus (PSbMV; genus Potyvirus, family Potyviridae) is an economically important viral pathogen of pea (Pisum sativum L.) in the United States and other legumeproducing world regions (Ali and Randles 1997; Beck et al. 2018; Congdon et al. 2016; Wunch et al. 2014). Multiple pathotypes of PSbMV have been described based on the variation in the pathogenic responses triggered on specific pea genotypes by each organism (Alconero et al. 1986; Ali and Randles 1997; Hjulsager et al. 2002; Kasimor et al. 1997). These pathotypes include P1, P2 or L, P3, P4, U-1, and U-2. PSbMV is transmitted in a nonpersistent manner by aphid vectors such as the pea aphid (Acyrthosiphon pisum), potato aphid (Macrosiphum euphorbiae), and green peach aphid (Myzus persicae) (Gonzalez and Hagedorn 1971); however, at least 21 aphid species have demonstrated the ability to transmit the virus (Khetarpal and Maury 1987). The pea aphid is considered the most important vector of PSbMV in the Pacific Northwestern United States (Clement et al. 2010). The pathotypes also vary in their rate of seed transmission (Kohnen et al. 1995) and symptomology in P. sativum (Alconero et al. 1986). Pathotype P1 is the most common strain of PSbMV and causes the most significant economic damage to the pea industry

${ }^{\dagger}$ Corresponding author: L. D. Porter; lyndon.porter@ars.usda.gov

Funding: This research was supported by the United States Department of Agriculture (USDA) Agricultural Research Service. The use of trade, firm, or corporation names in this publication is for the information and convenience of the reader. Such use does not constitute an official endorsement or approval by the United States Department of Agriculture (USDA) or the Agricultural Research Service of any product or service to the exclusion of others that may be suitable. USDA is an equal opportunity provider and employer.

The author(s) declare no conflict of interest.

Accepted for publication 29 December 2019.

This article is in the public domain and not copyrightable. It may be freely reprinted with customary crediting of the source. The American Phytopathological Society, 2020. worldwide (Maury and Khetarpal 1992). Symptoms of PSbMV-P1 include reduced internode length, mosaic discoloration of leaves, downward curling of leaf margins, malformation of terminal rosettes, splitting of the seed coat, aborted seeds, and mosaic on the seed, all of which ultimately lead to reduction in seed yield and quality (Ali and Randles 1998).

Resistance to PSbMV-P1 has been extensively studied and linked to the $s b m l$ gene found on chromosome 6 in P. sativum (Timmerman et al. 1993). This gene has subsequently been linked to the elongation initiation factor, eIF4E (Gao et al. 2004), a common gene conferring resistance to potyviruses across different plant hosts, including pepper ( $p v r 1$ and pvr2; Kang et al. 2005; Ruffel et al. 2002), lettuce (mo1; Nicaise et al. 2003), tomato (pot-1; Piron et al. 2010; Ruffel et al. 2005), and bean ( $b c$; Naderpour et al. 2010). Mutations found within the $e I F 4 E$ gene of $P$. sativum were associated with resistance to PSbMV-P1 (Gao et al. 2004; Smýkal et al. 2010). These mutations reside in the cap binding pocket of eIF4E, suggesting that structural differences may prevent the eIF4E translation initiation factor from functioning in viral gene expression (Gao et al. 2004). Interestingly, a cell-to-cell trafficking function was also identified for the dominant eIF4E factor, suggesting that the resistant eIF4E alleles may block intercellular movement of PSbMV (Gao et al. 2004). The recessive genes $s b m 2, s b m 3$, and $s b m 4$ have been linked to $P$. sativum resistance to PSbMV pathotypes P2, P3, and P4 (Hjulsager et al. 2002; Johansen et al. 2001; Provvidenti and Alconero 1988). Genes $s b m 1, s b m 3$, and $s m b 4$ cluster in the same linkage group VI, whereas $s b m 2$ was mapped to linkage group II (Provvidenti and Alconero 1988; Provvidenti and Muehlbauer 1990).

Previous studies have screened $P$. sativum germplasm for resistance to PSbMV and have identified several $e I F 4 E$ resistant alleles (Konečná et al. 2014; Smýkal et al. 2010). In one study, three different variants comprising nine alleles $\left(e I F 4 E^{A-1-2-3-4-5-6-7}, e I F 4 E^{B-1}\right.$, and $e I F 4 E^{C-2}$ ) were identified conferring resistance to PSbMV-P1 in a comprehensive screen of $P$. sativum germplasm (Konečná et al. 2014). Germplasm from the U.S. P. sativum Core Collection belonged to the $e I F 4 E^{A}$ variants. Five common resistance allele amino acid changes were identified in these variants, including W62L, AA73-74DD, S78, G107R, and N169K, in addition to 
differences in intron 3 size (Gao et al. 2004; Konečná et al. 2014; Smýkal et al. 2010). These mutations lead to disruption of the binding pocket and likely prevent the viral genome-linked protein ( $\mathrm{VPg})$ from binding with the $P$. sativum cell translation initiation complex (Gao et al. 2004). The PSbMV VPg has been identified as the pathogenicity determinant for pathotype P1, so disruption of the binding pocket could prevent the interaction of $P$. sativum eIF4E with PSbMV VPg. In comparison, the pathogenicity determinant of pathotype P4 is the P3-6k1 cistron (Johansen et al. 2001).

The goal of this study was to design and validate two kompetitive allele-specific PCR (KASP) genotyping markers that target the $P$. sativum eIF4E gene for the identification of PSbMV-resistant pea lines originating from the U.S. P. sativum Core Collection. A similar approach was used in Phaseolus vulgaris L., in which molecular markers were successfully generated for the differentiation of PveIF4E haplotypes that confer resistance of common bean to the potyvirus Clover yellow vein virus (Hart and Griffiths 2013), indicating that this strategy may be successful in P. sativum. The development of such markers would allow pea breeders worldwide to more rapidly screen new material for resistance to PSbMV, as opposed to conducting labor-intensive greenhouse grow-outs, virus inoculations and enzyme-linked immunosorbent assay (ELISA) screenings, or PCR testing with subsequent restriction enzyme digestion. Frew et al. (2002), Gao et al. (2004), and Smýkal et al. (2010) all identified markers for PSbMV resistance in eIF4E using PCR analyses and/or restriction enzyme digestion such as the random amplified polymorphic DNA or restriction fragment length polymorphism techniques, but these tools can be timely and more difficult to analyze and reproduce between laboratories. Therefore, the cost- and time-saving benefit of KASP markers will ultimately profit growers seeking to plant improved virus-resistant germplasm.

\section{Materials and Methods}

Virus isolate. PSbMV inoculum originated from infected pea seed of the Dark Skin Perfection variety taken from a field with infected plants in southeastern Washington State in the 1990s. Seed infected with the virus was grown in a greenhouse at the U.S. Department of Agriculture Agricultural Research Service (USDA-ARS) research station in Prosser, Washington. Emerged seedlings showed signs of PSbMV infection, including stunting, leaf mosaic, and downward curling of leaf margins. Dark Skin Perfection is resistant to pathotypes P2 and P3 but susceptible to the other pathotypes (Hjulsager et al. 2002; Olsen and Johansen 2001), suggesting that the isolate present could be pathotype P1 or P4. Screening P. sativum accessions PI 269774 and PI 269818 for resistance to the PSbMV isolate in this study identified the accessions as resistant. Accessions PI 269774 and PI 269818 have known resistance to PSbMV-P1 and PSbMVP2 but susceptibility to PSbMV-P3 and PSbMV-P4 (Alconero et al. 1986; Hjulsager et al. 2002). The susceptibility of Dark Skin Perfection to the PSbMV isolate used in this study, as well as the resistance of PI 269774 and PI 269818, indicates that the isolate was PSbMV-P1.

Total nucleic acid extraction. All plant tissue ( 0.20 to $0.21 \mathrm{~g}$ ) was subjected to a total nucleic acid extraction protocol (Torok and Randles 2007), in which leaf tissue was ground in a mesh grinding bag (Bioreba AG, Kanton Reinach, Switzerland) with $1.25 \mathrm{ml}$ of cetyl trimethyl ammonium bromide and $600 \mu \mathrm{l}$ was transferred to a 1.5-ml Eppendorf tube. The tubes were incubated at $60^{\circ} \mathrm{C}$ for $30 \mathrm{~min}$ before $600 \mu \mathrm{l}$ of chloroform isoamyl alcohol was added. Tubes were then vortexed and centrifuged for $10 \mathrm{~min}$ at $13,000 \times g$, and $500 \mu \mathrm{l}$ of the aqueous phase was transferred to new tubes. A total of $450 \mu$ l of cold isopropanol and $50 \mu \mathrm{l}$ of $3 \mathrm{M}$ sodium acetate was added. Tubes were inverted eight times and incubated at $-20^{\circ} \mathrm{C}$ for $16 \mathrm{~h}$. After incubation, nucleic acids were pelleted by centrifugation at $13,000 \times g$ for $2 \mathrm{~min}$, followed by a $500-\mu 1$ ethanol wash. Any remaining ethanol was removed following a last centrifugation step; after drying, the pellets were resuspended in $200 \mu \mathrm{l}$ of $\mathrm{H}_{2} \mathrm{O}$.

Reverse transcription PCR analysis of PSbMV isolates. After total nucleic acid extraction from the leaf tissue, a slightly modified reverse transcription (RT)-PCR protocol described by Torok and Randles (2007) was used to confirm that the pathotype isolated in the Dark Skin Perfection seed was PSbMV-P1. To target the PSbMV HC-Pro coding sequence of PSbMV, a $25-\mu$ l reaction consisting of $12.5 \mu \mathrm{l}$ of $2 \times$ reaction mix, $0.25 \mu \mathrm{l}$ of $20 \mu \mathrm{M}$ forward primer VT03 (5'-GTGTTGGAGGAATCACACCAGAAGAATGTG-3'), $0.25 \mu \mathrm{l}$ of $20 \mu \mathrm{M}$ reverse primer VT02 (5'-GCAGTTGCTACATC CATCATTGTTGGCCAT-3'), $0.5 \mu l$ of Superscript III RT/ Platinum Taq Enzyme Mix (Thermo Fisher Scientific, Waltham, MA), $10.5 \mu \mathrm{l}$ of $\mathrm{H}_{2} \mathrm{O}$, and $1 \mu \mathrm{l}$ of nucleic acid extract was used. The PCR program included a RT step at $45^{\circ} \mathrm{C}$ for $15 \mathrm{~min}$, followed by $2 \mathrm{~min}$ at $94^{\circ} \mathrm{C}$ and 35 cycles of $94^{\circ} \mathrm{C}$ for $30 \mathrm{~s}, 62^{\circ} \mathrm{C}$ for $30 \mathrm{~s}$, and $72^{\circ} \mathrm{C}$ for $1 \mathrm{~min}$, with a final extension at $72^{\circ} \mathrm{C}$ for $5 \mathrm{~min}$. PCR reactions were purified using the GeneJET PCR Purification Kit (Thermo Fisher Scientific) and subjected to direct sequencing (Molecular Cloning Laboratories, South San Francisco, CA). Sequences were compared with PSbMV-P1 (GenBank accession D10930.1), a pathotype P2 isolate (AJ252242.1), and a pathotype P4 isolate (X89997.1) using the Clustal Omega program, and it was determined that the unknown PSbMV strain showed $98.17 \%$ identity of its amino acid sequence to pathotype P1 and only 94.82 and $91.77 \%$ identity to pathotypes P2 and P4, respectively. The PSbMV strain used for all pathogenicity analyses in this study was considered a P1 pathotype.

Plant materials. Seed from all $P$. sativum accessions used in this study, except for the original PSbMV-infected seed, originated from the USDA-ARS Western Regional Plant Introduction Station located in Pullman, Washington.

PSbMV greenhouse screening. Forty-four $P$. sativum accessions were chosen for this study because information regarding their sensitivity to PSbMV-P1, as well as PSbMV-P2, -P3, and -P4, was available from previous publications (Hjulsager et al. 2002; Provvidenti and Alconero 1988). PSbMV disease ratings for these accessions included susceptible, resistant, and some with heterogeneity for resistance owing to accessions containing an assortment of seed based on their original collection method and submission to the U.S. P. sativum Core Collection (Table 1). The Dark Skin Perfection variety was used for both the inoculated and noninoculated control plants, as the PSbMV strain originally was isolated from this line. A total of four seeds of each $P$. sativum accession and Dark Skin Perfection were planted in a single 5-inch clay pot in compost soil for each trial. Trials were repeated for a total of eight plants per accession (except for accession PI 357038). For accession PI 357038, only seven plants were screened, as one seed did not germinate. Because sample size was limited to seven or eight plants, it is possible that heterogeneity of resistance in some accessions went undetected, thus failing to confirm previous reports of heterogeneity (Alconero et al. 1986; Timmerman et al. 1993). Plants were grown in a greenhouse with a 16-h photoperiod with temperatures ranging between 21.1 and $29.4^{\circ} \mathrm{C}$.

At 13 to 14 days postplanting, plants were mechanically inoculated with a PSbMV-P1 inoculum slurry modified from Aapola et al. (1974). The inoculum consisted of crude plant extracts prepared by grinding $0.5 \mathrm{~g}$ of leaf tissue in $2 \mathrm{ml}$ of $0.01 \mathrm{M}$ neutral potassium phosphate buffer with a mortar and pestle and adding $0.02 \mathrm{~g}$ of Diatomaceous Earth (Sigma, St. Louis, MO) to the slurry. Plants were mechanically inoculated using the same method a second time at 18 to 19 days postplanting to ensure successful pathogen infection.

ELISA analysis. At approximately 1 month postplanting, visual disease symptoms were recorded for each individual plant. At 40 days postplanting, leaf tissue $(0.20$ to $0.21 \mathrm{~g})$ from each plant was collected using sterile forceps and tested by double antibody sandwich ELISA using antibodies received from Nano Diagnostics LLC (Fayetteville, AR) that were specific for PSbMV. The provided manufacturer's protocol was used to perform all ELISA analyses. Plates were read at $405 \mathrm{~nm}$, and samples were compared with buffer only, PSbMV-positive samples (sample received in kit), and PSbMVnegative controls (sample received in kit), with a relative light unit cutoff of 0.1 .

Development of KASP markers. Sequences of the $P$. sativum eIF4E gene generated by Konečná et al. (2014) were aligned and analyzed in order to design the KASP primers. Sequences of $e I F 4 E-$ susceptible alleles from $P$. sativum included GenBank KF981389, KF981390, and KF981397 (eIF4E $E^{S-2, S-3}$; Konečná et al. 2014). 
Sequences of eIF4E-resistant $P$. sativum included GenBank KF981398, KF981394, KF981395, and KF981396, designated herein as the Resistant 1 genotype $\left(e I F 4 E^{A-1, A-4, A-5}\right.$; Konečná et al. 2014), and GenBank KF06565 and KF053455, designated herein as the Resistant 2 genotype $\left(e I F 4 E^{A-6, A-7}\right.$; Konečná et al. 2014). Alignment of these sequences identified three single nucleotide polymorphisms (SNPs) between the susceptible and Resistant 1 alleles, a single SNP between the susceptible and Resistant 2 alleles, and seven SNPs between the susceptible allele and both resistant eIF4E genotypes 1 and 2. In addition, alignment identified a 50-basepair gap in the Resistant 1 genotype compared with the susceptible and Resistant 2 genotypes and a 3-basepair gap in the Resistant 2 genotype compared with the susceptible and Resistant 1 genotypes.

Design of the KASP marker from the sequence alignment identified two locations within the $e I F 4 E$ gene that could be targeted because the surrounding sequence structure was conducive for primer

Table 1. List of 44 Pisum sativum accessions previously typed for resistance to Pea seedborne mosaic virus (PSbMV) pathotypes P1, P2, P3, and P4 compared with the kompetitive allele-specific PCR (KASP) marker results

\begin{tabular}{|c|c|c|c|c|c|c|}
\hline $\begin{array}{l}\text { GRIN pea } \\
\text { accession }^{\mathrm{a}}\end{array}$ & $\begin{array}{l}\text { GRIN database resistance } \\
\text { data }^{\mathrm{a}}\end{array}$ & $\begin{array}{c}\text { Pathotype } \\
\text { resistance } \\
\text { P1/P2/P3/P4 }\end{array}$ & $\underset{(n)^{\mathbf{c}}}{\text { Plants }}$ & $\begin{array}{c}\text { Greenhouse } \\
\text { observations }^{\text {d }}\end{array}$ & $\begin{array}{l}\text { PSbMV ELISA } \\
\text { results }^{\mathrm{e}}\end{array}$ & $\underset{\text { marker }}{\text { KASP }}$ \\
\hline PI 193584 & Heterogeneous for resistance & $\mathrm{R} / \mathrm{R} /-/ \mathrm{R}$ & 8 & None & 8 negative & $\mathrm{R} 1$ \\
\hline PI 193586 & Resistant & $\mathrm{R} / \mathrm{R} / \mathrm{R} / \mathrm{R}$ & 8 & $1 \mathrm{mM}, 1 \mathrm{mC}, 6$ none & 8 negative & $\mathrm{R} 1$ \\
\hline PI 347421 & Resistant & $\mathrm{R} / \mathrm{R} /-/ \mathrm{R}$ & 8 & None & 8 negative & $\mathrm{R} 1$ \\
\hline PI 347442 & Resistant & $\mathrm{R} / \mathrm{R} /-\mathrm{R}$ & 8 & None & 8 negative & $\mathrm{R} 1$ \\
\hline PI 347452 & Resistant & $\mathrm{R} / \mathrm{R} /-\mathrm{R}$ & 8 & $1 \mathrm{LD} / \mathrm{M}, 7$ none & 8 negative & $\mathrm{R} 1$ \\
\hline PI 347455 & Heterogeneous for resistance & $\mathrm{R} / \mathrm{R} /-/ \mathrm{R}$ & 8 & None & 8 negative & $\mathrm{R} 1$ \\
\hline PI 347456 & Heterogeneous for resistance & $\mathrm{R} / \mathrm{R} /-\mathrm{R}$ & 8 & None & 8 negative & $\mathrm{R} 1$ \\
\hline PI 347464 & Heterogeneous for resistance & $\mathrm{S} / \mathrm{R} /-/ \mathrm{R}$ & 8 & $1 \mathrm{mC}, 7$ none & 8 negative & $\mathrm{R} 1$ \\
\hline PI 347465 & Resistant & $\mathrm{R} / \mathrm{R} /-/ \mathrm{R}$ & 8 & None & 8 negative & $\mathrm{R} 1$ \\
\hline PI 347466 & Resistant & $\mathrm{R} / \mathrm{R} /-/ \mathrm{R}$ & 8 & $2 \mathrm{mC}, 6$ none & 8 negative & $\mathrm{R} 1$ \\
\hline PI 347467 & Heterogeneous for resistance & $\mathrm{R} / \mathrm{R} /-/ \mathrm{R}$ & 8 & $4 \mathrm{mM}, 4$ none & 8 negative & $\mathrm{R} 1$ \\
\hline PI 347468 & Heterogeneous for resistance & $\mathrm{R} / \mathrm{R} /-/ \mathrm{R}$ & 8 & None & 8 negative & $\mathrm{R} 1$ \\
\hline PI 347469 & Heterogeneous for resistance & $\mathrm{R} / \mathrm{R} /-/ \mathrm{R}$ & 8 & $2 \mathrm{mC} / \mathrm{mM}, 6$ none & 8 negative & $\mathrm{R} 1$ \\
\hline PI 347485 & Resistant & $\mathrm{R} / \mathrm{R} /-/ \mathrm{R}$ & 8 & None & 8 negative & $\mathrm{R} 1$ \\
\hline PI 347487 & Resistant & $\mathrm{R} / \mathrm{R} /-/ \mathrm{R}$ & 8 & $4 \mathrm{mVD}, 4$ none & 8 negative & $\mathrm{R} 1$ \\
\hline PI 347492 & Heterogeneous for resistance & $\mathrm{R} / \mathrm{R} / \mathrm{R} / \mathrm{R}$ & 8 & None & 8 negative & $\mathrm{R} 1$ \\
\hline PI 347494 & Resistant & $\mathrm{R} / \mathrm{R} /-/ \mathrm{R}$ & 8 & $3 \mathrm{mC}, 5$ none & 8 negative & $\mathrm{R} 1$ \\
\hline PI 347523 & Heterogeneous for resistance & $\mathrm{R} / \mathrm{R} /-/ \mathrm{R}$ & 8 & None & 8 negative & $\mathrm{R} 1$ \\
\hline PI 356984 & Resistant & $\mathrm{R} / \mathrm{R} /-\mathrm{R}$ & 8 & None & 8 negative & $\mathrm{R} 1$ \\
\hline PI 357003 & Resistant & $\mathrm{R} / \mathrm{R} /-/ \mathrm{R}$ & 8 & None & 8 negative & $\mathrm{R} 1$ \\
\hline PI 357005 & Resistant & $\mathrm{R} / \mathrm{R} /-/ \mathrm{R}$ & 8 & None & 8 negative & $\mathrm{R} 1$ \\
\hline PI 357015 & Resistant & $\mathrm{R} / \mathrm{R} /-/ \mathrm{R}$ & 8 & None & 8 negative & $\mathrm{R} 1$ \\
\hline PI 357023 & Resistant & $\mathrm{R} / \mathrm{R} /-/ \mathrm{R}$ & 8 & None & 8 negative & $\mathrm{R} 1$ \\
\hline PI 357026 & Resistant & $\mathrm{R} / \mathrm{R} /-/ \mathrm{R}$ & 8 & None & 8 negative & $\mathrm{R} 1$ \\
\hline PI 357038 & Resistant & $\mathrm{R} / \mathrm{R} /-/ \mathrm{R}$ & 7 & $1 \mathrm{VD}, 6$ none & 7 negative & $\mathrm{R} 1$ \\
\hline PI 378158 & Resistant & $\mathrm{R} / \mathrm{R} /-/ \mathrm{R}$ & 8 & None & 8 negative & $\mathrm{R} 1$ \\
\hline PI 269774 & Resistant & $\mathrm{R} / \mathrm{R} / \mathrm{S} / \mathrm{S}$ & 8 & None & 8 negative & $\mathrm{R} 2$ \\
\hline PI 269818 & Resistant & $\mathrm{R} / \mathrm{R} / \mathrm{S} / \mathrm{S}$ & 8 & None & 8 negative & $\mathrm{R} 2$ \\
\hline PI 175877 & Susceptible & $\mathrm{S} / \mathrm{R} /-/ \mathrm{S}$ & 8 & $\mathrm{C} / \mathrm{M} / \mathrm{LD}$ & 8 positive & $\mathrm{S}$ \\
\hline PI 314795 & Susceptible & $\mathrm{S} / \mathrm{S} /-/ \mathrm{S}$ & 8 & $4 \mathrm{M}, 4 \mathrm{mC}$ & 8 positive & $\mathrm{S}$ \\
\hline PI $343305^{*}$ & Susceptible & S/S/-/S & 8 & $5 \mathrm{C} / \mathrm{M}, 3$ none & 5 positive/ 3 negative & S/- (S) \\
\hline PI 343328 & Susceptible & $\mathrm{S} / \mathrm{S} /-/ \mathrm{S}$ & 8 & $\mathrm{C} / \mathrm{M} / \mathrm{VD}$ & 8 positive & $\mathrm{S}$ \\
\hline PI 343333 & Susceptible & $\mathrm{S} / \mathrm{S} /-/ \mathrm{S}$ & 8 & $\mathrm{C} / \mathrm{M}$ & 8 positive & S \\
\hline PI 347328 & Resistant & $\mathrm{R} / \mathrm{R} /-/ \mathrm{R}$ & 8 & $\mathrm{C} / \mathrm{M} / \mathrm{VD} / \mathrm{LD}$ & 8 positive & $\mathrm{S}$ \\
\hline PI 347420 & Susceptible & $\mathrm{S} / \mathrm{R} /-/ \mathrm{S}$ & 8 & $\mathrm{C} / \mathrm{M} / \mathrm{LD}$ & 8 positive & $S$ \\
\hline PI 347422 & Susceptible & $\mathrm{S} / \mathrm{R} /-/ \mathrm{R}$ & 8 & $\mathrm{C} / \mathrm{M} / \mathrm{LD}$ & 8 positive & S \\
\hline PI 347482 & Susceptible & $\mathrm{S} / \mathrm{R} /-/ \mathrm{S}$ & 8 & $\mathrm{C} / \mathrm{M}$ & 8 positive & S \\
\hline PI 347484 & Susceptible & $\mathrm{S} / \mathrm{R} /-/ \mathrm{S}$ & 8 & $7 \mathrm{C} / \mathrm{M}, 1$ none & 8 positive & S \\
\hline PI 347528 & Susceptible & $\mathrm{S} / \mathrm{R} /-/ \mathrm{S}$ & 8 & $\mathrm{C} / \mathrm{M}$ & 8 positive & S \\
\hline PI 193587 & Heterogeneous for resistance & $\mathrm{R} / \mathrm{R} /-/ \mathrm{R}$ & 8 & $6 \mathrm{C} / \mathrm{M}, 2$ none & 6 positive/2 negative & $\mathrm{S} / \mathrm{R} 1$ \\
\hline PI 193835 & Heterogeneous for resistance & $\mathrm{R} / \mathrm{R} /-/ \mathrm{R}$ & 8 & $2 \mathrm{C}, 6$ none & 2 positive/6 negative & $\mathrm{S} / \mathrm{R} 1$ \\
\hline PI $193836^{*}$ & Heterogeneous for resistance & $\mathrm{R} / \mathrm{S} /-/ \mathrm{S}$ & 8 & $6 \mathrm{C} / \mathrm{M}, 2$ none & 6 positive/2 negative & $\mathrm{S} /-(\mathrm{S} / \mathrm{R} 1)$ \\
\hline PI 347329 & Susceptible & $\mathrm{S} / \mathrm{R} /-/ \mathrm{R}$ & 8 & $7 \mathrm{C} / \mathrm{M} / \mathrm{LD}, 1$ none & 7 positive/1 negative & $\mathrm{S} / \mathrm{R} 1$ \\
\hline PI 347470 & Resistant & $\mathrm{R} / \mathrm{R} /-/ \mathrm{R}$ & 8 & $1 \mathrm{C} / \mathrm{M}, 1 \mathrm{LD}, 6$ none & 1 positive/7 negative & $\mathrm{S} / \mathrm{R} 1$ \\
\hline
\end{tabular}

${ }^{a}$ United States Germplasm Resource Information Network (GRIN) database accession numbers and listed resistance to PSbMV-P1.

${ }^{b}$ Resistance to pathotypes P1, P2, P3, and P4 as described in Hjulsager et al. (2002) and Provvidenti and Alconero (1988). R = resistance and S = susceptible. A dash indicates that no data is available.

c Total number of plants screened in the greenhouse for resistance to PSbMV-P1.

${ }^{\mathrm{d}}$ Greenhouse observations taken before leaf collection for enzyme-linked immunosorbent assay (ELISA). Symptoms observed for all or a portion of the eight plants screened include curling (C), mosaic (M), vein discoloration (VD), and leaf deformity (LD). Some observed symptoms were mild, including mild curling $(\mathrm{mC})$, mild mosaic $(\mathrm{mM})$, and mild vein discoloration $(\mathrm{mVD})$. "None" indicates when no PSbMV-P1 symptoms were observed for all plants or a portion of screened plants when a number is indicated.

e Results obtained from ELISA analyses per individual plant screened in the greenhouse.

${ }^{f}$ KASP results obtained from a single plant per accession except for accessions PI 193587, PI 193835, PI 347329, and PI 347470, where two plants from each accession were analyzed by KASP to assess single plants with different ELISA results. Accessions PI 343305 and PI 193836 (indicated with an asterisk) showed heterogenous ELISA results but were not accessed for the KASP marker of the ELISA-negative plant. As a result, 20 single plants from each accession were tested by KASP marker analysis and results are listed in parentheses. 
design. KASP marker SBM1_R1snp was designed to distinguish the Resistant 1 eIF4E allele from the susceptible and the Resistant 2 alleles, by targeting a W62L amino acid change from the susceptible to the Resistant 1 allele. To distinguish pea accessions that have the eIF4E Resistant 2 allele, the SBM1_R2del KASP marker was designed by targeting a $\mathrm{S} 78$ amino acid deletion found in this resistant allele. The codominant KASP markers were verified and generated by LGC Limited (Middlesex, United Kingdom) (Table 2).

KASP marker analysis of greenhouse-grown plants. After nucleic acid extraction, KASP marker analysis was performed using the protocol outlined by LGC Limited. The reaction mix consisted of $5 \mu 1$ of $2 \times$ KASP master mix, $0.14 \mu 1$ of KASP assay mix (containing primers specific to the Resistant 1 or Resistant 2 eIF4e alleles), and $5 \mu \mathrm{l}$ of $10 \mathrm{ng} / \mu \mathrm{l}$ DNA extract. Isolation and detection of the Resistant 1 and Resistant 2 eIF4e alleles was done using specific primers in assay mix SBM1_R1snp and SBM1_R2del, respectively (Table 2).

KASP analysis was performed on a LightCycler 480 (Roche, Indianapolis, IN) with the following thermal cycling conditions: a hot-start step at $15 \mathrm{~min}$ with a ramp rate of $4.4^{\circ} \mathrm{C} / \mathrm{s} ; 10$ cycles of a touchdown step at $94^{\circ} \mathrm{C}$ for $20 \mathrm{~s}$ with a ramp rate of $4.4^{\circ} \mathrm{C} / \mathrm{s}$, followed by $61^{\circ} \mathrm{C}$ for $1 \mathrm{~min}$ at a ramp rate of $2.2^{\circ} \mathrm{C} / \mathrm{s}$ with a step size of $0.6^{\circ} \mathrm{C}$ to the secondary target of $55^{\circ} \mathrm{C} ; 26$ cycles of a two-step PCR at $94^{\circ} \mathrm{C}$ for $20 \mathrm{~s}$ with a ramp rate of $4.4^{\circ} \mathrm{C} / \mathrm{s}$ and $55^{\circ} \mathrm{C}$ for $1 \mathrm{~min}$ with a ramp rate of $2.2^{\circ} \mathrm{C} / \mathrm{s}$; and a final plate read step at $37^{\circ} \mathrm{C}$ for $1 \mathrm{~min}$ with a ramp rate of $2.2^{\circ} \mathrm{C} / \mathrm{s}$ and the single acquisition at $37^{\circ} \mathrm{C}$ for $1 \mathrm{~s}$ with a ramp rate of $4.4^{\circ} \mathrm{C} / \mathrm{s}$. A recycling plate assay was subsequently used to form tight clusters after the initial run. The recycle program consisted of the following thermal cycling conditions: an amplification step with three cycles of a two-step PCR program of $94^{\circ} \mathrm{C}$ for $20 \mathrm{~s}$ with a ramp rate of $4.4^{\circ} \mathrm{C} / \mathrm{s}$ and $57^{\circ} \mathrm{C}$ for 1 min with a ramp rate of $2.2^{\circ} \mathrm{C}$; and a final plate read step at $37^{\circ} \mathrm{C}$ for $1 \mathrm{~min}$ with a ramp rate of $2.2^{\circ} \mathrm{C}$, and the single acquisition at $37^{\circ} \mathrm{C}$ for $1 \mathrm{~s}$ with a ramp rate of $4.4^{\circ} \mathrm{C} / \mathrm{s}$. For analysis of the data acquisition, LightCycler 480 endpoint genotyping software was used.

\section{Results}

Symptom expression of inoculated plants. Inoculated Dark Skin Perfection (PSbMV-susceptible control) and 10 different accessions consistently showed symptoms of PSbMV infection, including leaf curling, deformity, mosaic, and vein discoloration (Table 1). Accessions showing these symptoms included PI 175877, PI 314795, PI 343328, PI 343333, PI 347328, PI 347420, PI 347422, PI 347482 , PI 347484, and PI 347528. Fifteen additional accessions showed leaf curling, mosaic, or vein discoloration ranging from very mild to moderate levels for a subset of the seven or eight plants screened. The remaining 19 accessions did not show any symptoms of PSbMV infection, similar to the noninoculated Dark Skin Perfection control.

ELISA analysis. Forty-four pea accessions were characterized into three different phenotypic groups (susceptible, resistant, and heterogenous for resistance) based on detection of PSbMV by ELISA analysis of the individual plants from each accession (Table 1). Here, PSbMV was not detected from any of the seven or eight individual plants from 28 accessions. Most of these accessions were previously designated resistant, but nine were previously identified heterogenous for resistance (PI 193584, PI 347455, PI 347456, PI 347464,
PI 347467, PI 347468, PI 347469, PI 347492, and PI 347523) (Alconero et al. 1986; Provvidenti and Alconero 1988; Timmerman et al. 1993). Nine of these 28 accessions expressed symptoms similar to those observed for PSbMV-P1 but virus was not detected in the plants, indicating that these observed symptoms of mild curling, mosaic, or vein discoloration were likely a result of other non-PSbMVrelated variables.

PSbMV was detected by ELISA in 10 accessions that showed clear visual PSbMV symptoms. These accessions were previously identified as susceptible except for PI 347328, which was designated as resistant (Provvidenti and Alconero 1988). For six accessions, PSbMV was only detected by ELISA in a portion of the plants (Table 1). Three of these accessions were previously designated as heterogeneous for resistance (PI 193587, PI 193835, and PI 193836), whereas two were designated as susceptible (PI 343305 and PI 347329) and one was designated as resistant (PI 347470) (Provvidenti and Alconero 1988). Virus was not detected by ELISA in control Dark Skin Perfection pea plants that were not inoculated with PSbMV-P1 but was detected in inoculated Dark Skin Perfection plants.

KASP marker analysis. Of the 28 accessions that showed an absence of virus detection by ELISA, end-point genotyping analysis identified 26 accessions as having the eIF4E Resistant 1 allele (Fig. 1; Table 1). For four of the six accessions (PI 193587, PI 193835, PI 347329, and PI 347470) in which PSbMV was only detected in a portion of the plants, nucleic acids were extracted from both resistant and susceptible plant tissue. The SBM1_R1snp KASP

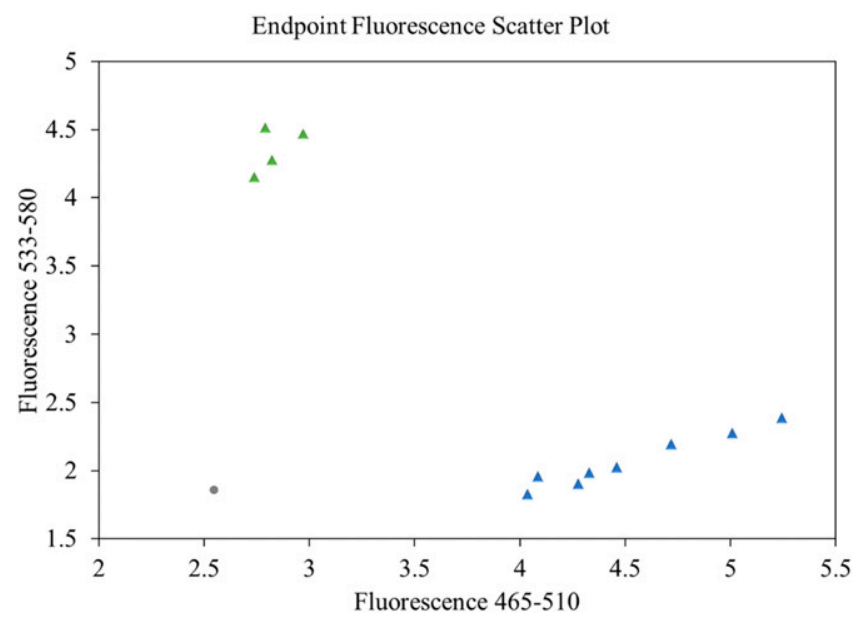

Fig. 1. End-point genotyping with kompetitive allele-specific PCR marker SBM1 R1snp to identify accessions with the Resistant 1 elF4E allele. Fluorescent signal (represented by the triangles at a fluorescence $465-510$ between 2.5 and 3 ) identified samples with the W62L mutation conferring resistance to Pea seedborne mosaic virus pathotype P1 (PSbMV-P1) and isolated these from samples either susceptible to PSbMV-P1 or with the second type of resistance to PSbMV-P1 (represented by the triangles at a fluorescence $465-510$ between 4 and 5.5). The no template control (NTC) is represented by the filled circle on the graph. The Dark Skin Perfection (DSP) variety was used as the susceptible control.

Table 2. Kompetitive allele-specific PCR (KASP) markers used to distinguish two different $e I F 4 E$ resistant alleles ${ }^{\mathrm{a}}$

\begin{tabular}{|c|c|c|c|c|c|}
\hline Primer name & Primer_AlleleFAM ${ }^{b}$ & Primer_AlleleHEX ${ }^{b}$ & Primer_Common & AlleleFAM ${ }^{c}$ & AlleleHEX \\
\hline SBM1_R1snp & $\begin{array}{l}\text { CCTCGAGAATTCT } \\
\text { TGGACTTTCTG }\end{array}$ & $\begin{array}{l}\text { CTCCTCGAGAATT } \\
\text { CTTGGACTTTCTT }\end{array}$ & $\begin{array}{l}\text { TGGATTTTGCTG } \\
\text { CGGGGGTATCAAA }\end{array}$ & G & $\mathrm{T}$ \\
\hline SBM1_R2del & $\begin{array}{l}\text { GAAAGTGTAGATGG } \\
\text { GTCGCATTGAA }\end{array}$ & $\begin{array}{l}\text { AAAGTGTAGATGG } \\
\text { GTCGCATTGAG }\end{array}$ & $\begin{array}{r}\text { TACCCCCGCAGCA } \\
\text { AAATCCAAACAA }\end{array}$ & - & AGC \\
\hline
\end{tabular}

\footnotetext{
a Primers and fluorophores listed distinguish resistant genotype 1 (SBM1_R1snp) and resistant genotype 2 (SBM1_R2del) from the susceptible $e$ IF4E allele and the alternate resistant allele.

${ }^{\mathrm{b}}$ In each KASP reaction, two fluorescence resonance energy transfer cassettes are present containing complementary sequences to the allele-specific tail sequence of each allele-specific primer. Upon binding to the complementary region, the fluorophores (FAM $=$ fluorescein or HEX = hexachlorofluorescein) are released from the quencher, allowing for detection of the amplification products at wavelengths between 495 to $520 \mathrm{~nm}$ and 538 to $555 \mathrm{~nm}$ for FAM and HEX, respectively.

c The dash indicates that AlleleFAM contains a three-basepair deletion compared to AlleleHEX.
} 
marker identified the eIF4E Resistant 1 allele in the ELISA-negative plants for all four accessions (Table 1). The remaining ELISApositive plants were identified as having the susceptible or Resistant 2 alleles based on the SBM1_R1snp KASP marker. Analysis of the remaining 10 accessions with the KASP SBM1_R1snp marker identified the accessions as either susceptible to PSbMV-P1 or having the Resistant 2 allele. For accessions PI 193836 and PI 343305, only the plants in which PSbMV was detected by ELISA analysis were collected for KASP marker analysis. With the SBM1_R1snp KASP marker, these samples were identified as having either the susceptible or Resistant 2 alleles. Since a sample from the plants in which PSbMV was not detected by ELISA was not initially collected from these two accessions, 20 plants were subsequently planted and KASP marker analyses were conducted for each accession. Here, KASP analysis with the SBM1-R1snp marker identified four plants of PI 193836 as having the Resistant 1 allele, whereas the remaining 16 plants of PI 193836 and all 20 plants of PI 343305 were identified as either susceptible or having the Resistant 2 allele.

Among the accessions identified with the eIF4E-Resistant 1 allele were seven pea lines with sequences already present in GenBank (Konečná et al. 2014). These included GenBank accessions KF981391 (PI 193586), KF981392 (PI 347492), KF981393 (PI 193835), KF981394 (PI 347464), KF981395 (PI 378158), KF981396 (PI 347494), and KF981429 (PI 193584). Sequences from these seven pea lines all contained the SNP present in the eIF4E Resistant 1 allele that results in a W62L amino acid change, confirming that the KASP primers correctly identified the SNP of interest.

Of the 44 total accessions in this study, end-point genotyping analysis using KASP marker SBM1_R2del identified two accessions containing the eIF4e-Resistant 2 allele (Fig. 2; Table 1). These two accessions were resistant to PSbMV-P1 based on visual and ELISA analyses. The remaining 42 accessions were either susceptible to PSbMV-P1 or had the Resistant 1 allele based on the SBM1_ R2del KASP marker. The 20 plants collected from accessions PI 193836 and PI 343305 were also analyzed using the SBM1_R2del KASP marker, of which no samples were identified with the Resistant 2 allele.

The two accessions identified with the eIF4E Resistant 2 allele had sequences already present in GenBank (Konečná et al. 2014), designated as KF053454 (PI 269774) and KF053455 (PI 269818). Both sequences contained the 3-nucleotide deletion that generates the S78 amino acid deletion found in the eIF4E Resistant 2 allele. These

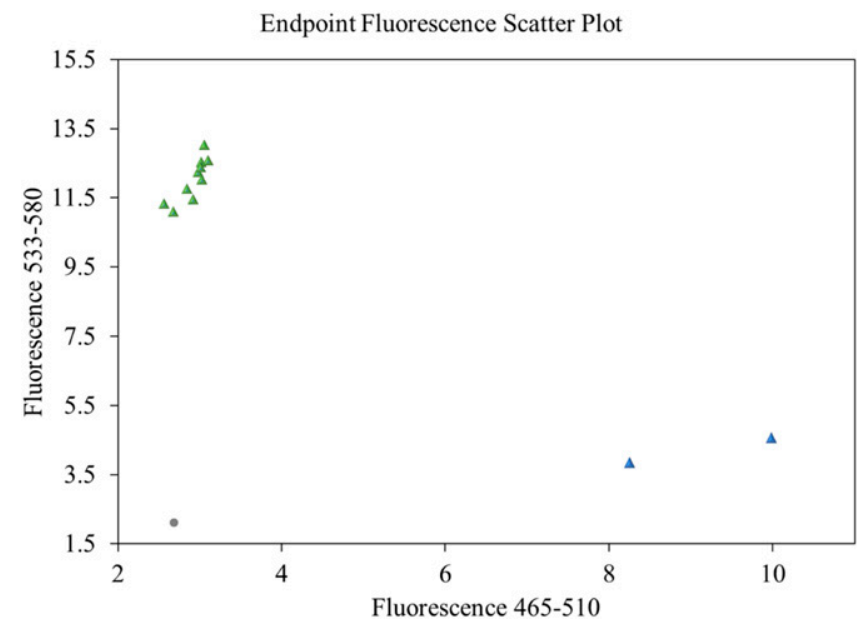

Fig. 2. End-point genotyping with kompetitive allele-specific PCR marker SBM1_R2del to identify accessions with the Resistant 2 elF4E allele. Fluorescent signal (represented by the triangles at a fluorescence $465-510$ between 8 and 10) identified samples with the S78 deletion conferring resistance to Pea seedborne mosaic virus pathotype P1 (PSbMV-P1) and isolated these from samples either susceptible to PSbMV-P1 or with the first type of resistance to PSbMV (represented by the triangles at a fluorescence $465-510$ between 2 and 4). The no template control (NTC) is represented by the filled circle on the graph. The Dark Skin Perfection (DSP) variety was used as the susceptible control. sequences confirm that the KASP primers are able to correctly identify the S78 deletion of interest.

Analysis of all 44 pea lines with both KASP markers identified accessions that did not carry either the eIF4E-Resistant 1 or 2 allele. For these 10 accessions, accession PI 343305, and the five accessions with mixed seed (heterogenous for resistance), it was deduced that they contain the $e I F 4 E$ susceptible allele (Table 1). These accessions were classified as susceptible based on symptom expression and virus infection status determined by ELISA, confirming the results from the KASP marker analysis. In addition, three of these 10 accessions were previously sequenced (Konečná et al. 2014) and listed in GenBank as accessions KF981389 (PI 347484), KF981390 (PI 347422), and KF981397 (PI 347328). All of these sequences contain the susceptible genotype at amino acids 62 and 78, confirming the KASP marker analysis results. For accession PI 343305, three plants were identified as PSbMV negative by ELISA; however, of the 20 additional seeds tested, no resistant alleles were identified, designating this line as susceptible. It is possible that this discrepancy in ELISA results and the follow-up KASP analysis is attributable to incomplete inoculation of the plants tested by ELISA. The discrepancy between ELISA results and KASP marker analysis was only seen for this single accession.

\section{Discussion}

In $P$. sativum, several allelic variants were previously identified within the $e I F 4 E$ gene that confer resistance to PSbMV-P1 (Konečná et al. 2014). One allele, designated as the eIF4E Resistant 1 allele in this study, contains three SNPs and a 50-basepair gap within an intron, compared with the $e I F 4 E$ susceptible allele. A second resistant allele, designated as the $e I F 4 E$ Resistant 2 allele, contains a single SNP and a 3-basepair gap compared with the susceptible allele. The initial goal of this study was to identify, generate, and validate a single KASP marker that would differentiate both $e I F 4 E$ Resistant 1 and 2 alleles from the susceptible allele. Unfortunately, because of the complexity of the genome and differences between all three eIF4E alleles of interest, a single KASP marker could not be developed. As a result, two different KASP markers were designed to distinguish the eIF4E Resistant 1 and 2 alleles, and a total of 44 accessions found in the United States Germplasm Resource Information Network (GRIN) database with resistant or susceptible phenotypes were screened for verification.

Both KASP markers designed in this study, SBM1_R1snp and SBM1_R2del, successfully identified the two PSbMV-P1 resistant alleles and confirmed ELISA results generated from a greenhouse screen for resistance to PSbMV-P1. Of the 28 resistant accessions, 26 pea lines contained the eIF4E Resistant 1 allele, whereas only

Table 3. The relationship of the resistance profile of 39 Pisum sativum accessions (excluding accessions with heterogeneity) previously screened for resistance to Pea seedborne mosaic virus (PSbMV) pathotypes P1, P2, and P4 (Provvidenti and Alconero 1988) to the profile of the kompetitive allelespecific PCR (KASP) marker identifying resistance to PSbMV pathotype $\mathrm{P}^{\mathrm{a}}$

\begin{tabular}{lccccc}
\hline Marker & RRR $^{\mathbf{b}}$ & RRS & SRR & SRS & SSS \\
\hline Resistance 1 & $100\left(26^{\mathrm{c}}\right)$ & $0(0)$ & $0(0)$ & $0(0)$ & $0(0)$ \\
Resistance 2 & $0(0)$ & $66.7(2)$ & $0(0)$ & $0(0)$ & $0(0)$ \\
Susceptible & $0(0)$ & $0(0)$ & $18.2\left(2^{\mathrm{d}}\right)$ & $45.5(5)$ & $36.4(4)$ \\
Frequency & $26 / 39$ & $2 / 39$ & $2 / 39$ & $5 / 39$ & $4 / 39$ \\
\hline
\end{tabular}

a A percentage is listed for each profile, followed by the number of accessions in parentheses.

$\mathrm{b}$ The first, second, and third letters represent the resistance of accession to PSbMV pathotypes $\mathrm{P} 1, \mathrm{P} 2$, and $\mathrm{P} 4$, respectively. $\mathrm{R}=$ resistant and $\mathrm{S}=$ susceptible.

c Accession PI 347464 was listed as SRR by Provvidenti and Alconero (1988) but Timmerman et al. (1993) demonstrated PSbMV-P1 resistance, indicating a heterogenous population exists. The accession was considered as RRR based on the enzyme-linked immunosorbent assay (ELISA) and KASP marker results from this study.

d Accession PI 347328 was listed as RRR by Provvidenti and Alconero (1988) but was included as SRR based on the ELISA and KASP marker results from this study. 
two pea lines contained the eIF4E Resistant 2 allele. All five of the heterogenous accessions identified by KASP marker analysis contained the eIF4E Resistant 1 allele as well. These results indicate that the eIF4E Resistant 1 allele is more common than the other resistant allele in the initial lines obtained from GRIN. Pea accessions containing the Resistant 1 allele are listed as originating from countries such as India, Ethiopia, and Malaysia. Unfortunately, the true origin of the two accessions containing the Resistant 2 allele is unknown because these samples are likely not from the United Kingdom, as indicated in GRIN. It would not be surprising if the two different $e I F 4 E$ alleles evolved from two distinct regions of origin, as it is likely that each resistant population originated from a single event prior to dispersal. Different haplotypes of the $e I F 4 E$ gene that confer resistance to bymoviruses in barley have been associated with specific geographic regions around the world (Hofinger et al. 2011), suggesting that the same could be true for PSbMV-P1 resistance in pea.

Although both the Resistant 1 and 2 alleles identify accessions with resistance to PSbMV-P1, comparison of PSbMV-P1, -P2, $-\mathrm{P} 3$, and -P4 resistance identified by Provvidenti and Alconero (1988) and Hjulsager et al. (2002) suggests that these markers could be used to identify $\mathrm{P} 2$ and $\mathrm{P} 4$ resistance. A relationship profile for 39 of the 44 accessions analyzed in this study identified all 26 pea lines with the $e I F 4 E$ Resistant 1 allele as having resistance to pathotypes P2 and P4 as well (Table 3). The two pea lines identified with the eIF4E Resistant 2 allele only showed additional resistance to pathotype P2. All pea lines with the susceptible $e I F 4 E$ allele fell into three groups: those with resistance to $\mathrm{P} 2$ and $\mathrm{P} 4$, those with resistance only to $\mathrm{P} 2$, and those with no known resistance to PSbMV pathotypes. The relationships identified in the resistance profile indicate that breeders could use the Resistance 1 allele to select advanced breeding lines because resistance associated with this allele is also associated with lines having resistance to PSbMV-P2, -P3, and -P4. Incorporation of the Resistance 2 allele into breeding programs likely will not lead to overall PSbMV resistance, as it is associated with accessions that may or may not be resistant to PSbMV-P3 and -P4, based on previous literature (Table 1).

The successful development of codominant KASP markers that target pea lines with resistance to PSbMV-P1 will be beneficial to pea breeders worldwide because it allows for the rapid identification of heterozygous germplasm and the determination of allelic frequency within a population. Currently, greenhouse screens and ELISA analyses are used to identify resistant pea lines, requiring large amounts of greenhouse space, time, and money to perform inoculations, observations of PSbMV symptoms, and ELISA tests. As demonstrated in this study, observations from greenhouse screens are not always $100 \%$ consistent with ELISA analyses, perhaps owing to missed inoculation or other greenhouse variables, suggesting that ELISA screens are a necessary step if genetic markers are not utilized to identify resistant lines. As an alternative, the KASP markers developed herein can be used with end-point genotyping to rapidly screen new breeding lines for resistance to PSbMV-P1 without requiring extensive greenhouse screens or ELISA analyses to retrieve results. Use of these KASP markers will save breeders time and money, which will ultimately result in improved germplasm for pea growers and producers.

\section{Acknowledgments}

We thank Clare Coyne (United States GRIN) for preparing and providing the $P$. sativum accessions utilized in this study. We thank Ginny Coffman and Rebecca Cochran for technical assistance in the greenhouse and laboratory.

\section{Literature Cited}

Aapola, A. A., Knesek, J. E., and Mink, G. I. 1974. The influence of inoculation procedure on the host range of Pea seed-borne mosaic virus. Phytopathology 64:1003-1006

Alconero, R., Provvidenti, R., and Gonsalves, D. 1986. Three Pea seedborne mosaic virus pathotypes from pea and lentil germ plasm. Plant Dis. 70:783-786.

Ali, A., and Randles, J. W. 1997. Early season survey of pea viruses in Pakistan and the detection of two new pathotypes of pea seedborne mosaic potyvirus. Plant Dis. 81:343-347.

Ali, A., and Randles, J. W. 1998. The effects of two pathotypes of Pea seed-borne mosaic virus on the morphology and yield of pea. Australas. Plant Pathol. 27:226-233.
Beck, A. L., Simons, K. J., and Pasche, J. S. 2018. Occurrence of Pea seed-borne mosaic virus in field peas in North Dakota. Plant Dis. 102:1466.

Clement, S. L., Husebye, D. S., and Eigenbrode, S. D. 2010. Ecological factors influencing pea aphid outbreaks in the US Pacific Northwest. Pages 107-128 in: Aphid Biodiversity Under Environmental Change. P. Kindlmann, A. Dixon, and J. Michaud, eds. Springer, Dordrecht, Netherlands.

Congdon, B. S., Coutts, B. A., Renton, M., Banovic, M., and Jones, R. A. C. 2016 Pea seed-borne mosaic virus in field pea: Widespread infection, genetic diversity and resistance gene effectiveness. Plant Dis. 100:2475-2482.

Frew, T. J., Russell, A. C., and Timmerman-Vaughan, G. M. 2002. Sequence tagged site markers linked to the $s b m l$ gene for resistance to pea seedborne mosaic virus in pea. Plant Breed. 121:512-516.

Gao, Z., Johansen, E., Eyers, S., Thomas, C. L., Ellis, T. H. N., and Maule, A. J. 2004. The potyvirus recessive resistance gene, $s \mathrm{bm} 1$, identifies a novel role for translation initiation factor eIF4E in cell-to-cell trafficking. Plant J. 40: 376-385.

Gonzalez, L., and Hagedorn, D. J. 1971. The transmission of Pea seedborne mosaic virus by three aphid species. Phytopathology 61:825-828.

Hart, J. P., and Griffiths, P. D. 2013. A series of eIF4E alleles at the $B c-3$ locus are associated with recessive resistance to Clover yellow vein virus in common bean. Theor. Appl. Genet. 126:2849-2863.

Hjulsager, C. K., Lund, O. S., and Johansen, I. E. 2002. A new pathotype of Pea seedborne mosaic virus explained by properties of the P3-6k1 and viral genome-linked protein (VPg)-coding regions. Mol. Plant-Microbe Interact. 15:169-171.

Hofinger, B. J., Russell, J. R., Bass, C. G., Baldwin, T., Dos Reis, M., Hedley, P. E., Li, Y., Macaulay, M., Waugh, R., Hammond-Kosack, K. E., and Kanyuka, K. 2011. An exceptionally high nucleotide and haplotype diversity and a signature of positive selection for the $e I F 4 E$ resistance gene in barley are revealed by allele mining and phylogenetic analyses of natural populations. Mol. Ecol. 20:3653-3668.

Johansen, I. E., Lund, O. S., Hjulsager, C. K., and Laursen, J. 2001. Recessive resistance in Pisum sativum and Potyvirus pathotype resolved in a gene-forcistron correspondence between host and virus. J. Virol. 75:6609-6614.

Kang, B.-C., Yeam, I., Frantz, J. D., Murphy, J. F., and Jahn, M. M. 2005. The pvr1 locus in Capsicum encodes a translation initiation factor eIF4E that interacts with Tobacco etch virus VPg. Plant J. 42:392-405.

Kasimor, K., Baggett, J. R., and Hampton, R. O. 1997. Pea cultivar susceptibility and inheritance of resistance to the lentil strain (pathotype P2) of Pea seedborne mosaic virus. J. Am. Soc. Hortic. Sci. 122:325-328.

Khetarpal, R. K., and Maury, Y. 1987. Pea seed-borne mosaic virus: A review. Agronomie 7:215-224.

Kohnen, P. D., Johansen, I. E., and Hampton, R. O. 1995. Characterization and molecular detection of the $\mathrm{P} 4$ pathotype of Pea seedborne mosaic potyvirus. Phytopathology 85:789-793.

Konečná, E., Šafářová, D., Navrátil, M., Hanáček, P., Coyne, C., Flavell, A. Vishnyakova, M., Ambrose, M., Redden, R., and Smýkal, P. 2014. Geographical gradient of the $e I F 4 E$ alleles conferring resistance to potyviruses in pea (Pisum) germplasm. PLoS One 9:e90394.

Maury, Y., and Khetarpal, K. R. 1992. Pea seedborne mosaic virus. Pages 74-92 in: Plant Diseases of International Importance. Volume II: Diseases of Vegetables and Oil Seed Crops. H. S. Chaube, U. S. Singh, and A. N. Murkhopadhya, eds. Prentice-Hall, Englewood Cliffs, NJ.

Naderpour, M., Øgaard, S., Lund, O., and Johansen, E. 2010. A possible role for $B C-U$ in $B C-U, B C-3$ gene combination in resistance to Bean common mosaic virus in Phaseolus vulgaris L. Annu. Rep. Bean Improv. Coop. 53:46-47.

Nicaise, V., German-Retana, S., Sanjuán, R., Dubrana, M.-P., Mazier, M., Maisonneuve, B., Candresse, T., Caranta, C., and Le Gall, O. 2003 Molecular characterization of $\mathrm{mol}$, a recessive gene associated with Lettuce mosaic potyvirus resistance in lettuce. Pages 143-148 in: Proceedings of the EUCARPIA Meeting on Leafy Vegetables Genetics and Breeding, Noordwijkerhout, Netherlands, 19-21 March 2003. T. J. L. van Hintum, A. Lebeda, D. A. Pink, and J. W. Schut, eds. Centre for Genetic Resources, Wageningen, Netherlands.

Olsen, B. S., and Johansen, I. E. 2001. Nucleotide sequence and infectious cDNA clone of the L1 isolate of pea seed-borne mosaic potyvirus. Arch. Virol. 146 $15-25$

Piron, F., Nicolaï, M., Minoïa, S., Piednoir, E., Moretti, A., Salgues, A., Zamir, D., Caranta, C., and Bendahmane, A. 2010. An induced mutation in tomato eIF4E leads to immunity to two potyviruses. PLoS One 5:e11313.

Provvidenti, R., and Alconero, R. 1988. Sources of resistance to pathotypes of Pea seed-borne mosaic virus in the U.S. plant introductions of Pisum sativum. Pisum Newsl. 20:30-31.

Provvidenti, R., and Muehlbauer, F. J. 1990. Evidence of a cluster of linked genes for resistance to Pea seedborne mosaic virus and Clover yellow vein virus on chromosome 6. Pisum Newsl. 22:43-45.

Ruffel, S., Dussault, M.-H., Palloix, A., Moury, B., Bendahmane, A., Robaglia, C., and Caranta, C. 2002. A natural recessive resistance gene against potato virus $Y$ in pepper corresponds to the eukaryotic initiation factor 4E (eIF4E). Plant J. 32: 1067-1075.

Ruffel, S., Gallois, J. L., Lesage, M. L., and Caranta, C. 2005. The recessive potyvirus resistance gene pot-1 is the tomato orthologue of the pepper pvr2 eIF4E gene. Mol. Genet. Genomics 274:346-353. 
Smýkal, P., Šafářová, D., Navrátil, M., and Dostalová, R. 2010. Marker assisted pea breeding: eIF4E allele specific markers to Pea seed-borne mosaic virus (PSbMV) resistance. Mol. Breed. 26:425-438.

Timmerman, G. M., Frew, T. J., Miller, A. L., Weeden, N. F., and Jermyn, W. A. 1993. Linkage mapping of $s b m 1$, a gene conferring resistance to Pea seed-borne mosaic virus, using molecular markers in Pisum sativum. Theor. Appl. Genet. 85:609-615.
Torok, V. A., and Randles, J. W. 2007. Discriminating between isolates of PSbMV using nucleotide sequence polymorphisms in the HC-Pro coding region. Plant Dis. 91:490-496.

Wunch, M., Pasche, J., Knodel, J., McPhee, K., Markell, S., Chapara, V., and Pederson, S. 2014. Pea seed-borne mosaic virus in field peas and lentils. Bulletin PP1704. North Dakota Agricultural Experiment Station, Fargo, ND, USA. 